\title{
Deciphering intracellular events triggered by mild magnetic hyperthermia in vitro and in vivo
}

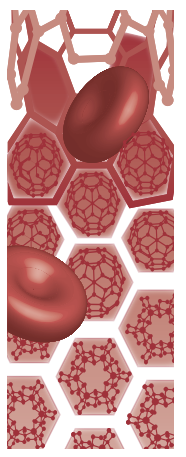

\begin{abstract}
Aim: To assess the cell response to magnetic nanoparticles under an alternating magnetic field by molecular quantification of heat responsive transcripts in two model systems. Materials \& methods: Melanoma cells and Hydra vulgaris treated with magnetic nanoparticles were subjected to an alternating magnetic field or to macroscopic heating. Effect to these treatments were assessed at animal, cellular and molecular levels. Results: By comparing hsp70 expression following both treatments, thermotolerance pathways were found in both systems in absence of cell ablation or global temperature increment. Conclusion: Analysis of hsp70 transcriptional activation can be used as molecular thermometer to sense cells' response to magnetic hyperthermia. Similar responses were found in cells and Hydra, suggesting a general mechanism to the delivery of sublethal thermal doses.
\end{abstract}

Keywords: heat shock proteins $\bullet$ Hydra vulgaris $\bullet$ magnetic nanoparticles $\bullet$ murine melanoma cells • sublethal hyperthermia

The rapid evolution of nanotechnology offers smart nanomaterials for the development of forefront strategies in nanomedicine. Magnetic iron oxide nanoparticles (MNPs) have gained growing attention because of their chemical stability, ease of synthesis and negligible cytotoxic effects [1,2]. Moreover, their magnetic properties make them ideal candidates to be used in a plethora of biomedical applications including imaging, transfection, bioseparation and controlled drug delivery $[3,4]$. Most interestingly, as a consequence of hysteresis energy loss and Neel or Brown relaxation [5-7], MNPs are capable to produce heat under an appropriate alternating magnetic field (AMF), a phenomena known as magnetic hyperthermia (MHT). Since the pioneering application of MNPs for cancer therapy in 1957 [8], many progresses have been made and currently MNP-based hyperthermia is being evaluated in preclinical and clinical trials for adjuvant treatment of different types of tumors [9-12]. Classic approaches of hyperthermia, based mostly on the use of microwave radiation, implanted electrodes, ultrasounds and laser irradiation, present some practical limitations such as undesired burns of healthy tissues surrounding the targeted tissue, limited heat penetration and uncertain heat localization.

Magnetic hyperthermia provides tremendous advantages over those methods, in other words, the possibility to tailor MNP surfaces with bioactive molecules allowing specific targeting, the possibility to control at distance the temperature increments, MNPs acting as remote-switchable devices or restricting heat production to defined intracellular compartments.

Until recently, HT inducing a significant decrease in cancer cells viability was the most clinically relevant. This cytotoxic effect of temperature is assessed to occur at $>43^{\circ} \mathrm{C}[13]$. However, accurate measuring of the temperature is difficult to attain, and therefore, this type of HT has been associated with higher toxicity due to overheating of healthy tissues [14]. Nevertheless, to date, nonlethal HT is being applied in combination with various established cancer treatments [15]. Indeed
Maria Moros ${ }^{\ddagger}$, Alfredo

Ambrosone ${ }^{\ddagger, 2}$, Grazyna Stepien $^{\ddagger 1}$, Federica Fabozzi², Valentina Marchesano ${ }^{2}$, Anna Castaldi², Angela Tino ${ }^{2}$, Jesus M de la Fuente ${ }^{*, 1,3}$ \& Claudia Tortiglione $* *, 2$

'Instituto de Nanociencia de Aragon (INA), Universidad de Zaragoza, C/ Mariano Esquillor s/n, 50018 Zaragoza, Spain

2Istituto di Cibernetica "Eduardo Caianiello", Consiglio Nazionale delle Ricerche, Via Campi Flegrei, 34, 80078, Pozzuoli, Italy

${ }^{3}$ Instituto de Ciencia de Materiales de Aragon, CSIC-Universidad de Zaragoza. C/ Pedro Cerbuna 12, Zaragoza, Spain *Author for correspondence: Tel.: +34 976865448 jmfuente@unizar.es

**Author for correspondence:

Tel.: +390818675306

Fax +390818675126

claudia.tortiglione@cnr.it

${ }^{\ddagger}$ Authors contributed equally

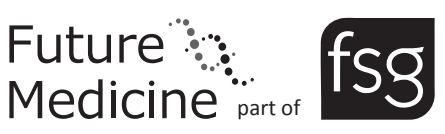


a synergistic interaction between heat and radiation therapy and/or chemotherapy has been confirmed in clinical trials $[16,17]$. Hence, investigation of sublethal HT effects is recently focusing a special attention. However, in spite of much progress in this type of HT in the last years, the clinical impact has been modest. It is thought that understanding of the molecular mechanisms underlying these cellular responses to mild hyperthermia will contribute to the enhancement of cancer therapy, namely by gaining knowledge on the acquired sensitivity of cells to ionizing radiation or the transient thermotolerance [18].

It is well known that the consequences of the heatinduced stress depend on temperature and exposure time at a specific temperature and as far as the temperature stress stimulus does not go beyond a certain threshold, the cell can cope with it [19]. The temperature deviations, which act on the cell, find a reflexion at the molecular level by the induced synthesis of heat shock proteins (HSPs) [20]. It has been widely reported that MHT can cause overexpression of HSP7O specially when high temperatures are reached [21], but the molecular response for temperature elevation can be much complex and unexplained, especially in the context of sublethal hyperthermia. Furthermore, in several recent studies it has been postulated that cells can respond diversely depending on the nature of the heating agents. MHT appears to be more efficient in inducing cell death in vitro than hot-water HT, suggesting that cell damage induced by AMF must be due to temperature-induced alterations in molecular pathways [22]. In principle, during MHT the heat generation is localized on the magnetic particles and dissipate immediately to surrounding microenvironment creating a temperature increase inside the cells. Although many approaches have been developed to measure MNP-localized increments of temperature in solution [23,24], much less attention has been dedicated to understand how the heat propagates inside biological environments and, even more interesting, what the cells really sense when intracellular hyperthermia occurs (in contrast with macroscopic heating).

Given the emerging clinical impact of MNPs, deciphering the mechanisms underlying cell response to nanoheaters appears an urgent need. In the present paper, we addressed this issue by investigating cell and molecular responses to mild MHT, showing that overexpression of chaperones can also take place without a global temperature increment. We used two different biological models, in vitro cultured cells (murine melanoma cells) and the aquatic invertebrate Hydra vulgaris, recently emerged as an excellent model for high-throughput screening of nanoparticles bioactivity and toxicity [25-29]. Normally cultured at $18^{\circ} \mathrm{C}$, Hydra offers the undeniable advantage to test the type and the intensity of the thermal stress produced by MHT, in a simple tissue-like structure. With the aim to characterize the cell response to MNPs in absence of cell ablation, we performed a comprehensive study in cells and in Hydra treated with MNPs and by means of animal, cell and molecular biology, we showed the modulation of the $h s p 70$ gene expression in both systems. By comparing the response of the two systems to the MNPmediated hyperthermia and to the external heating, we unexpectedly found similar responses in cells and Hydra, suggesting a general mechanism underlying the response of eukaryotic cells to the delivery of sublethal thermal doses. Moreover, we propose the quantitative analysis of $h s p 70$ transcriptional activation as novel molecular thermometers to sense the cell response to MNP-induced thermal solicitation, otherwise undetectable. To the best of our knowledge, this is the first time that mRNA levels are used to assess differences in cells' responses depending on the nature of the heating (MHT vs external heat).

\section{Materials \& methods}

\section{Synthesis \& functionalization of water-soluble MNPs}

Unless otherwise stated, all reagents were purchased from Sigma-Aldrich (MO, USA).

Monodisperse MNPs of $16.6 \pm 1.3 \mathrm{~nm}$ diameter were synthesized following the seed-mediated growth protocol described by Sun et al. [30]. First, $5 \mathrm{~nm}$ MNP seeds were synthesized by mixing and stirring under a flow of argon Iron (III) acetylacetonate $\mathrm{Fe}(\mathrm{acac})_{3}$ (1 eq), 1,2-hexadecanediol (17.4 eq), oleic acid (6.4 eq) and oleylamine (4.8 eq) solubilized in benzyl ether (26.7 $\mathrm{mM}$ with respect to $\mathrm{Fe}(\mathrm{acac})_{3}$ ). The mixture was heated to $200^{\circ} \mathrm{C}\left(180^{\circ} \mathrm{C} / \mathrm{h}\right)$ during $2 \mathrm{~h}$ and heated to reflux for $1 \mathrm{~h}$. After cooling down the MNPs, they were subsequently washed with ethanol, and re-dispersed in hexane. These MNPs were used as seeds to obtain $9 \mathrm{~nm}$ MNPs by mixing and stirring under a flow of argon the following chemicals: $\mathrm{Fe}(\mathrm{acac})_{3}(1 \mathrm{eq})$, 1,2-hexadecanediol ( $4.5 \mathrm{eq})$, oleic acid $(0.7 \mathrm{ml})$, oleylamine $(0.5 \mathrm{ml})$ and $5 \mathrm{~nm}$ MNP seeds $(31 \mathrm{mg} \mathrm{Fe})$ solubilized in benzyl ether $(100 \mathrm{mM}$ with respect to $\left.\mathrm{Fe}(\mathrm{acac})_{3}\right)$. The mixture was heated up to $100^{\circ} \mathrm{C}$ for $30 \mathrm{~min}$, to $200^{\circ} \mathrm{C}$ for $1 \mathrm{~h}$ and last heated to reflux for $30 \mathrm{~min}$. The mixture was washed as before. Finally, these MNPs were used as seeds to obtain $16.6 \mathrm{~nm}$ MNPs following this last procedure.

The transfer into water was performed using a modified protocol based on a previously reported method [31]. Briefly, $542 \mathrm{mg}$ of poly(maleic anhydridealt-1-octadecene); PMAO MW 30000-50000) was added to a flask containing $200 \mathrm{ml}$ of chloroform and 
placed in an ultrasonic bath. Twenty milligrams of MNPs diluted in $\mathrm{CHCl}_{3}$ were added drop-wise and the mixture was left in the ultrasonic bath for further $15 \mathrm{~min}$. The solvent was slowly removed under vacuum and $20 \mathrm{ml}$ of $0.05 \mathrm{M} \mathrm{NaOH}$ was added to transfer the MNPs to the aqueous phase. To remove the excess of unbound polymer, the solution was centrifuged at $75,600 \times g$ for $2 \mathrm{~h}$ twice.

Fluorescent MNPs were obtained by modifying the polymer with tetramethylrhodamine 5(6)-carboxamide cadaverine (TAMRA; Anaspec [Seraing, Belgium]). As already reported [32], 1\% of the polymer monomers were modified with TAMRA before transferring the MNPs into water.

Functionalization with glucose or PEG 750 Da was performed by incubating $1 \mathrm{mg}$ of MNPs with $3 \mathrm{mg}$ of $\mathrm{N}$-(3-dimethylaminopropyl)-N'-ethylcarbodiimide hydrochloride (EDC), $25 \mu \mathrm{mol}$ of 4-aminophenyl $\beta$-D-glucopyranoside or $\alpha$-methoxy- $\omega$-amino poly(ethylene glycol) $750 \mathrm{Da}$ (Rapp Polymere GmbH [Tuebingen, Germany]) in $250 \mu \mathrm{l}$ of SSB buffer $\mathrm{pH} 9$ ( $50 \mathrm{mM}$ of boric acid and $50 \mathrm{mM}$ of sodium borate). After $2 \mathrm{~h}$ of incubation, the ligand excess was removed by washing the MNPs with phosphate-buffered saline (PBS) $\mathrm{pH} 7.4$ in a centrifugal filter with a membrane of $100 \mathrm{kDa}$ molecular weight limit (Merck Millipore, Darmstadt, Germany).

\section{General procedures for MNP characterization}

MNPs were characterized using transmission electron microscopy (TEM; FEI Tecnai T20, OR, USA). Dynamic light scattering and zeta-potential ( $\zeta$-potential) measurements were performed on a Brookhaven Zeta PALS instrument (NY, USA) at $25^{\circ} \mathrm{C}$. DLS and $\zeta$-potential measurements were performed in water, combining ten runs per measurement. Iron was quantified using a standard colorimetric procedure already reported [23]. Briefly, the samples were allowed to incubate with aqua regia for $15 \mathrm{~min}$ at $60^{\circ} \mathrm{C}$ after which Milli-Q water was added to make up a volume of $500 \mu \mathrm{l} . \mathrm{KOH}$ and 4,5-dihydroxy-1,3-benzenedisulfonic acid disodium salt monohydrate were added to a final concentration of $0.9 \mathrm{~N}$ and $12 \mathrm{mM}$, respectively. Finally, $0.2 \mathrm{M}$ sodium phosphate buffer $\mathrm{pH} 9.7$ was added to make up a final volume of $210 \mu \mathrm{l}$ and the solution was left at room temperature for $15 \mathrm{~min}$. The sample's measurement of absorbance at $480 \mathrm{~nm}$ was carried out on a Thermo Scientific Multiskan ${ }^{\mathrm{TM}}$ GO UV/Vis microplate spectrophotometer (MA, USA). A calibration curve was performed following the same procedure using iron standard solution (Acros Organics, Geel, Belgium) as reference.

The specific absorption rate from the MNPs was performed on a DM100 system (nanoScale Biomag- netics, Zaragoza, Spain) operating at a frequency of $835.25 \mathrm{kHz}$ and a field of $20.05 \mathrm{kA} / \mathrm{m}$.

\section{Cell/animal culture \\ Cells}

Murine melanoma cell line B16-F10 (ATCC ${ }^{\circledR}$ number CRL-6475) was cultured at $37^{\circ} \mathrm{C}$ in a $5 \% \mathrm{CO}_{2}$ atmosphere in Dulbecco's modified Eagle's medium (DMEM ${ }^{\mathrm{TM}}$; Lonza, Basel, Switzerland) supplemented with $10 \%$ fetal bovine serum, $5 \%$ glutamine and 5\% penicillin/streptomycin.

\section{Hydra}

Hydra vulgaris (strain Zurich) were asexually cultured in Hydra medium $\left(1 \mathrm{mM} \mathrm{CaCl}_{2}, 0.1 \mathrm{mM} \mathrm{NaHCO}\right.$, $\mathrm{pH} 7$ ) according to the method of Loomis and Lenhoff with minor modifications [33]. The animals were fed 3-times a week, on alternate days, with Artemia nauplii and kept at $18^{\circ} \mathrm{C}$ with a $16: 8 \mathrm{~h}$ light:dark regimen.

\section{Viability \& toxicity testing \\ Cells}

To determine cell viability, MTT (3-(4,5-dimethylthiazol-2-yl)-2,5-diphenyltetrazolium) test was performed, and $1 \times 10^{4}$ cells were seeded in 96-well culture plates and cultured for $24 \mathrm{~h}$. MNPs functionalized with glucose at various concentrations $(50,100$ and $150 \mu \mathrm{g} \mathrm{Fe} / \mathrm{ml}$ ) were added in DMEM and incubated for $24 \mathrm{~h}$. Cells were thoroughly washed with DPBS and $20 \mu \mathrm{l}$ of MTT solution $(5 \mathrm{mg} / \mathrm{ml}$ in PBS) was added to each well. Following $4 \mathrm{~h}$ of incubation at $37^{\circ} \mathrm{C}$, formazan salts were dissolved with $200 \mu \mathrm{l}$ of DMSO and the absorbance (Abs) was determined at $\lambda=570 \mathrm{~nm}$ on a microplate reader (Thermo Scientific Multiskan GO UV/Vis microplate spectrophotometer). Control wells including cells treated with Triton X100 (positive control) or cells without MNPs (negative control) were also analyzed.

\section{Hydra}

Budless polyps were selected for in vivo experiments, performed in air-conditioned environment $\left(220^{\circ} \mathrm{C}\right)$. The tests were initiated by collecting groups of 15 animals in plastic multiwells, containing $300 \mu \mathrm{l}$ of Hydra medium, followed by the addition of MNPs functionalized with PEG at different concentrations (from 0.1 to $2.5 \mathrm{mg} \mathrm{Fe} / \mathrm{ml}$ ) and incubation for $24 \mathrm{~h}$. Following extensive washing, polyp morphology and tissue integrity were evaluated by optical microscopy. Adverse effects were scored through a morphological/behavioral evaluation of Hydra polyps. To test nanoparticle impact on Hydra growth, four polyps (with one bud) were treated with the indicated $2.5 \mathrm{mg} \mathrm{Fe} / \mathrm{ml}$, for $24 \mathrm{~h}$, then washed, and the following day placed in 
$3.5 \mathrm{~cm}$ Petri dishes (1 Hydra/dish). Control animals at the same developmental stage were not treated. Both treated and control Hydra were fed once daily. The growth rate constant (k) of Hydra population is defined as $\ln \left(n / n_{0}\right)=k t$ where $n$ is the number of animals at time $t$ and $n_{0}$ the number of animal at $t_{0}[31]$.

\section{Internalization study}

MNP internalization in cells and Hydra animals was confirmed by fluorescence microscopy (using MNPs modified with TAMRA), TEM and inductively coupled plasma atomic emission spectroscopy (ICP-AES) or inductively coupled plasma mass spectrometry (ICP-MS).

To perform fluorescence microscopy analysis, $1 \times 10^{5}$ cells were seeded on glass coverslips in a 24-well plate (TPP, Trasadingen, Switzerland). Twenty-four $h$ later, $50 \mu \mathrm{g} \mathrm{Fe} / \mathrm{ml}$ of MNPs functionalized with glucose were added in DMEM and left for $24 \mathrm{~h}$. Noninternalized MNPs were removed washing with PBS thrice. Cells were fixed with $4 \%$ formaldehyde for $20 \mathrm{~min}$ at $4^{\circ} \mathrm{C}$, washed twice with DPBS, and incubated for $10 \mathrm{~min}$ with DAPI for nuclei labeling. The coverslips were mounted on glass microscope slides. Fluorescence microscopy was performed using an inverted microscope (Nikon Eclipse Ti-E, Amsterdam, The Netherlands).

In case of Hydra animals, for in vivo fluorescence imaging, 25 polyps were soaked in culture medium supplemented with TAMRA-labeled MNPs $(2.5 \mathrm{mg}$ $\mathrm{Fe} / \mathrm{ml})$. After 24-h incubation, animals were relaxed in Hydra medium supplemented with urethane (2\% w/v) and inspected by an inverted microscope (Axiovert 100, Zeiss [Oberkochen, Germany]) equipped with a digital color camera (Olympus, DP70 [Olympus Optical Gmbh, Hamburg, Germany]). The software system Cell $\mathrm{F}$ (Olympus) was used for imaging acquisition and analysis.

For electron microscopy studies, 20,000 cells were seeded in 8-well chamberslide (Permanox ${ }^{\circledR}, \mathrm{Nunc}^{\circledR}$, NY, USA). Twenty-four h later, $50 \mu \mathrm{g} \mathrm{Fe} / \mathrm{ml}$ of MNPs functionalized with glucose were added in DMEM and left for $24 \mathrm{~h}$. Noninternalized MNPs were removed washing with $0.1 \mathrm{M}$ PBS and cells were subsequently fixed with $2.5 \%$ glutaraldehyde in $0.1 \mathrm{M}$ phosphate buffer (PB) for $2 \mathrm{~h}$ at $4^{\circ} \mathrm{C}$. Cells were washed four times using $0.1 \mathrm{M} \mathrm{PB}$. Sections were post-fixed with $2 \%$ osmium, rinsed, dehydrated and embedded in Durcupan resin. Semithin sections $(1.5 \mu \mathrm{m})$ were cut with an Ultracut UC-6 and stained lightly with $1 \%$ toluidine blue. Finally, ultrathin sections $(0.08 \mu \mathrm{m})$ were cut with a diamond knife, stained with lead citrate (Reynolds solution) and examined under a $200 \mathrm{kV}$ transmission electron microscope (FEI).
TEM analysis of Hydra polyps were performed as previously reported by our group [29]. Briefly, ten polyps were incubated in the presence of PEG-functionalized MNPs (2.5 mg Fe/ml). Animals were extensively washed upon 24-h incubation, they were anesthetized in urethane $(2 \% \mathrm{w} / \mathrm{v})$ and fixed for $2 \mathrm{~h}$ in $2 \%$ glutaraldehyde in Hydra medium, extensively washed and postfixed for $45 \mathrm{~min}$ with $1 \%$ buffered $\mathrm{OsO}_{4}$. After a series of four washes, animals were dehydrated in a graded ethanol and incubated $2 \times 15$ min with propylene oxide and then overnight in a 1:1 mixture of propylene oxide/EMbed 812 resin (Electron Microscopy Sciences, PA, USA). Before flat embedding, animals were incubated $2 \times 2 \mathrm{~h}$ in Epon 12 Resin. Sample serial thin $(70 \mathrm{~nm})$ section was cut with a diamond knife and mounted onto 150-200 mesh hexagonal tem grid (G200TT-Ni, Electron Microscopy Sciences). Thin sections were stained with uranyl acetate and lead citrate. Ultrathin sections were examined with Leo $912 \mathrm{AB}$ transmission electron microscope operating at $80 \mathrm{kV}$.

Intracellular iron determination was performed by ICP. For ICP measurements, $1 \times 10^{5}$ cells or 150 Hydra polyps incubated for $24 \mathrm{~h}$ with MNPs as explained before, were treated with $100 \mu \mathrm{l}$ of Piranha solution ( $>85 \%$ sulfuric acid and $>50 \%$ hydrogen peroxide) for $15 \mathrm{~min}$ and $300 \mu \mathrm{l}$ of aqua regia for $2 \mathrm{~h}$. Subsequently, the samples were incubated at $60^{\circ} \mathrm{C}$ for $15 \mathrm{~min}$ and diluted with Milli-Q water to $20 \mathrm{ml}$. Samples were evaluated by ICP-AES (Optima 8300, Perkin Elmer [MO, USA]) or ICP-MS (Xseries2, Thermo Scientific).

\section{Magnetic hyperthermia \& heat shock assays} AMF assays were performed on a DM100 system (nanoScale Biomagnetics) with a frequency of 835.25 $\mathrm{kHz}$ and a field of $20.05 \mathrm{kA} / \mathrm{m}$. Prior to every experiment, culture medium was subjected to AMF for $30 \mathrm{~min}$ in order to measure the bulk solution temperature. The bulk solution temperature was measured with an optic fiber sensor incorporated in the equipment.

\section{Cells}

Two glass cover slips seeded with $1 \times 10^{5}$ cells each and treated and nontreated with glucose-derivatized MNPs $(50 \mu \mathrm{g} \mathrm{Fe} / \mathrm{ml})$ were exposed to AMF for $30 \mathrm{~min}$ recording the obtained temperature ramp. In order to mimic the temperature ramp obtained by AMF, a similar experiment was set up by heating the sample at the same temperature ramp obtained by AMF. The experiments were carried out in duplicate.

Macroscopic heat shock was performed by exposing cells in an incubator to different temperatures (39, 41 and $43^{\circ} \mathrm{C}$ ) for $30 \mathrm{~min}$. Immediately after the treatment, 
cell viability was analyzed using Trypan blue staining. The experiments were carried out in triplicate.

\section{Hydra}

Untreated and PEG-derivatized MNPs (2.5 mg Fe/ml) treated animals were exposed to AMF for $30 \mathrm{~min}$ as in the case of cells. After AMF treatment, the animals were collected in a small Petri dish and employed for further investigations. Group of 20 polyps were employed for each test. The experiments were carried out in triplicate.

For macroscopic heat shock, 20 polyps for each experimental condition were incubated for $30 \mathrm{~min}$ in Hydra medium prewarmed at 18, 22, 26, 30, 34 and $37^{\circ} \mathrm{C}$. Experiments were carried out in triplicate.

\section{Cell death \& cell cycle analysis \\ Cells}

After AMF treatment, cells were incubated in standard growth conditions for $4 \mathrm{~h}$, washed twice with PBS and harvested. The relative percentage of cells undergoing early and late apoptosis was assessed using Annexin-FITC and propidium iodide (PI) following manufacturer's protocol (Immunostep, Salamanca, Spain). Flow cytometry was performed using a BD FACSARIATM (CA, USA) equipment.

For cellular cycle analysis, cells were allowed to recover $24 \mathrm{~h}$ after AMF treatment. Cells were harvested, washed with $\mathrm{PBS}$ and incubated in $1 \mathrm{ml}$ of cold ethanol for $24 \mathrm{~h}$ at $4^{\circ} \mathrm{C}$. After extensive washing with PBS, a buffer containing propidium iodide $(50 \mu \mathrm{g} / \mathrm{ml})$ and RNase A $(100 \mu \mathrm{g} / \mathrm{ml})$ was added and incubated for $30 \mathrm{~min}$. Samples were analyzed using a BD FACSArray (BD Biosciences).

\section{Hydra}

To assess the cell death, the number of phagocyted pyknotic nuclei indicative of apoptotic cell death was evaluated by 4',6-diamidino-2-phenylindole (DAPI) staining [34]. Briefly, untreated and MNP-treated polyps in presence or absence of AMF were macerated and the single-cell suspensions were fixed with 4\% paraformaldehyde and spread on slides. After extensive washing in PBS, macerates were stained with DAPI for 2 min and washed in PBS. Slides were observed with phase-contrast fluorescent microscopy to detect pyknotic nuclei. More than 300 cells were counted for each treatment and the percentage of apoptotic nuclei was determined. Propidium iodide staining $(100 \mu \mathrm{g} / \mathrm{ml}, 5$-min incubation) and fluorescence microscopy were used to detect necrotic cells in living polyps.

\section{Total RNA extraction \& RT-PCR analysis}

The expression of $h s p 70$ gene was investigated by real-time quantitative reverse transcription PCR
(qRT-PCR) in B16-F10 melanoma cells and Hydra animals subjected to MHT or external heating.

To study the kinetics of the heat shock response in B16-F10 melanoma cells, hsp70 (mHSP1ab, NCBI reference sequence: NM_010478.2) expression was analyzed at three time points after applying the AMF/external heating immediately after being exposed to the treatment $(0 \mathrm{~min})$, after $30 \mathrm{~min}$ and after $120 \mathrm{~min}$ of recovery from the treatment. During these postincubation times, cells were placed in standard growth conditions. Total RNA was extracted using the Total RNA Purification Kit (Norgen Biotek, Thorold, Canada) following the manufacturer's instructions. RNA concentration and purity was assessed by UV spectrophotometry (Thermo Scientific Multiskan GO UV/Vis microplate spectrophotometer) at 260 and $280 \mathrm{~nm}$, and running the samples in an agarose gel stained with Gel Red ${ }^{\mathrm{TM}}$ (Biotium, CA, USA).

A $1.5 \mu \mathrm{g}$ of RNA was treated by DNase (Promega, WI, USA) and the first cDNA strand was synthesized using SuperScript ${ }^{\circledR}$ VILO $^{\text {TM }}$ cDNA synthesis kit (Invitrogen, CA, USA) according to manufacturer's instructions. qRT-PCR was performed in $20 \mu \mathrm{l}$ of reaction mixture comprising $1 \mathrm{X}$ iTaq ${ }^{\mathrm{TM}}$ Universal SYBR $^{\circledR}$ Green Supermix (Biorad, CA, USA), serial dilutions of cDNA and $0.25 \mu \mathrm{M}$ each primer ( $h s p 70$ Forward primer: 5'-CGTGGAGGAGTTCAAGAGGAAG-3', Reverse primer: 5'-GCGTGATGGATGTGTAGAAGTC- $3^{\prime}$ ). The reactions were processed using the Bio-Rad CFX-96 Real Time PCR System under the following fast cycling steps: denaturation for $30 \mathrm{~s}$ at $95^{\circ} \mathrm{C}$, followed by 40 cycles at $95^{\circ} \mathrm{C}$ for $3 \mathrm{~s}$, $60^{\circ} \mathrm{C}$ for $30 \mathrm{~s}$. In addition, melting curves $(20 \mathrm{~min}$; from 59 to $90^{\circ} \mathrm{C}$ ) were generated to check undesired amplification products. The $h s p 70$ gene expression was normalized to the expression of the housekeeping gene gadph (NCBI reference sequence: XM_001479371.4. Forward primer: 5'-TGCCCCCATGTTTGTGATG-3'; reverse primer: 5'-TGTGGTCATGAGCCCTTCC-3'). Each qRT-PCR reaction was performed in triplicate. At least three technical repeats from two biological replicates were carried out.

Gene-expression profile of $h s p 70$ in Hydra (byhsp70, GenBank: DQ286045.1. Forward primer: cgacgtattcagacaatcaacc; reverse primer: caatttgaggaacacctcttgg) was evaluated after $30 \mathrm{~min}$ and $120 \mathrm{~min}$ AMF exposure/external heating. Total RNA was purified using Trizol ${ }^{\circledR}$ Reagent (Life Technologies) and its concentration was determined by SmartSpec plus spectrophotometer (Biorad). The first-strand cDNA was synthesized by High Capacity cDNA Reverse Transcription Kit (Applied Biosystem ${ }^{\circledR}$ ) using $0.5 \mu \mathrm{g}$ of DNA-free RNA in a final volume of $20 \mu \mathrm{l}$, according to the manufacturer's instructions. qRT-PCR was 
performed in $25 \mu$ of reaction mixture consisting of $1 \times$ Express Sybr ${ }^{\circledR}$ GreenER qPCR SuperMix with premixed ROX (Invitrogen), serial cDNA dilutions and $0.25 \mu \mathrm{M}$ each primer. The reactions were processed using the StepOne Real-Time PCR System (Applied Biosystem) under the following cycling steps: initial denaturation for $2 \mathrm{~min}$ at $94^{\circ} \mathrm{C}$, followed by 40 cycles at $94^{\circ} \mathrm{C}$ for $2 \mathrm{~s}, 59^{\circ} \mathrm{C}$ for $30 \mathrm{~s}$. In addition, melting curves $\left(20 \mathrm{~min}\right.$; from 59 to $\left.90^{\circ} \mathrm{C}\right)$ were generated to check undesired amplification products. Hydra EF HyEf-1 $\alpha$ (GenBank Accession number Z68181.1. Forward, 5'-CCAGGAGACAATGTCGGTTT; reverse 5'-GCTTCAATGGACGGATCATT-3') was used as internal reference gene. Three technical repeats from two biological replicates were carried out. Primers were designed using Primer3 software [35]. The delta-delta Ct (2- $\Delta \Delta \mathrm{CT})$ method, for comparing relative expression results between treatments, was applied both for cell and Hydra expression analyses [36].

\section{Results \& discussion}

\section{MNP synthesis \& functionalization}

Since magnetic properties are strongly dependent on the size and shape of MNPs, the synthesis of uniformly shaped MNPs with well-controlled size distribution is a key aspect for hyperthermia applications. We synthesized MNPs sizing $16.6 \mathrm{~nm} \pm 1.3 \mathrm{~nm}$ (Supplementary Figure 1, see online at www.futuremedicine.com/doi/full/10.2217/NNM.15.70) using a previously reported seed-mediated method, based on the thermal decomposition of $\mathrm{Fe}$ (III) acetylacetonate, as this methodology provides monodisperse MNPs with high crystallinity [30]. MNPs were prepared in organic solvents and coated with oleic acid, thus a subsequent transfer to aqueous solution was achieved following a modified version of a previously reported protocol (Supplementary Figure 2, in which the nanoparticles are coated and made a water-stable suspension by means of an amphiphilic polymer shell, poly[maleic anhydride-alt-1-octadecen] [PMAO]) [31].

In order to track in vitro and in vivo the internalization and the intracellular fate, MNPs were fluorescently labeled by transferring them into water using the amphiphilic polymer already modified with a conventional fluorescent dye (TAMRA) [32]. MNPs were subsequently modified with glucose or PEG as these two biomolecules have been previously described to improve stability of nanoparticles in physiological conditions and increase the cellular and Hydra uptake [29,32], respectively. The ability to dissipate heat under an AMF was measured by the specific absorption rate given in Watt per gram of iron, which for the present MNPs and experimental conditions $(f=835 \mathrm{kHz}$; $\mathrm{H}=20.05 \mathrm{kA} / \mathrm{m})$ was found equal to $376 \mathrm{~W} / \mathrm{g}_{\mathrm{Fe}}$.
Additional details of MNPs physico-chemical properties are reported in the supporting information (Supplementary Table 1, Supplementary Figures 1 \& 3).

\section{MNP toxicological impact \& internalization in} B16-F10 melanoma cells

B16-F10 mouse melanoma cells were incubated for $24 \mathrm{~h}$ with different doses of MNPs $(50,100$ and $150 \mu \mathrm{g} \mathrm{Fe} / \mathrm{ml})$. Cytotoxicity evaluation through MTT assay demonstrated that the cell viability was not significantly impaired (Figure 1A) by MNP treatments. By fluorescence microscopy, it was corroborated that $50 \mu \mathrm{g} \mathrm{Fe} / \mathrm{ml}$ was sufficient to provide high cell uptake (Figure 1B). A red punctuated labeling pattern, resulting from fluorescently labeled MNPs, was localized abundantly within the cytoplasm. To get more insights into the MNPs intracellular localization, TEM analysis showed MNPs mostly compartmentalized into endocytic vesicles (Figure $1 C \& D$ ). For further in vitro experiments the $50 \mu \mathrm{g} \mathrm{Fe} / \mathrm{ml}$ of MNPs was selected. The internalization rate of MNPs was quantified by inductively coupled plasma spectroscopy (ICP), estimating an intracellular Fe content of $0.294 \mu \mathrm{g}(0.49 \mathrm{pg}$ Fe/cell).

\section{Cell \& molecular responses to magnetic} nanoparticles mediated magnetic hyperthermia in melanoma cells

The main aim of this work was to assess the molecular effects caused by sublethal MHT after applying an AMF in cells incubated with MNPs. The recent interest for mild hyperthermia relies on the fact that while not inducing cytotoxicity effect per se [13], it can increase the efficiency of radiation therapy and/or chemotherapy. In fact, it can trigger a complex series of molecular and cellular responses. For instance, it has been described that a total number of 114 common genes, involved in cellular growth and maintenance pathways respond to mild hyperthermia in human cancer cells [37]. Unraveling these molecular responses may have a therapeutic interest.

Although it has been widely reported that MHT causes an increment of $h s p 70$, it remains unclear whether this overexpression is also induced by sublethal hyperthermia, in absence of a global temperature increment. Therefore, here the studies were designed so that the culture media (global) temperature never exceed $37^{\circ} \mathrm{C}$ when applying the AMF. In order to minimize the effect of transient increase of the temperature due to different rates of heat generation and dissipation using an adiabatic AMF applicator [38], the intrinsic temperature of cell medium following AMF application at the instrument maximum frequency $(f=835 \mathrm{kHz} ; \mathrm{H}=20.05 \mathrm{kA} / \mathrm{m})$, was carried out for 30 min. This measurement showed that a starting temper- 


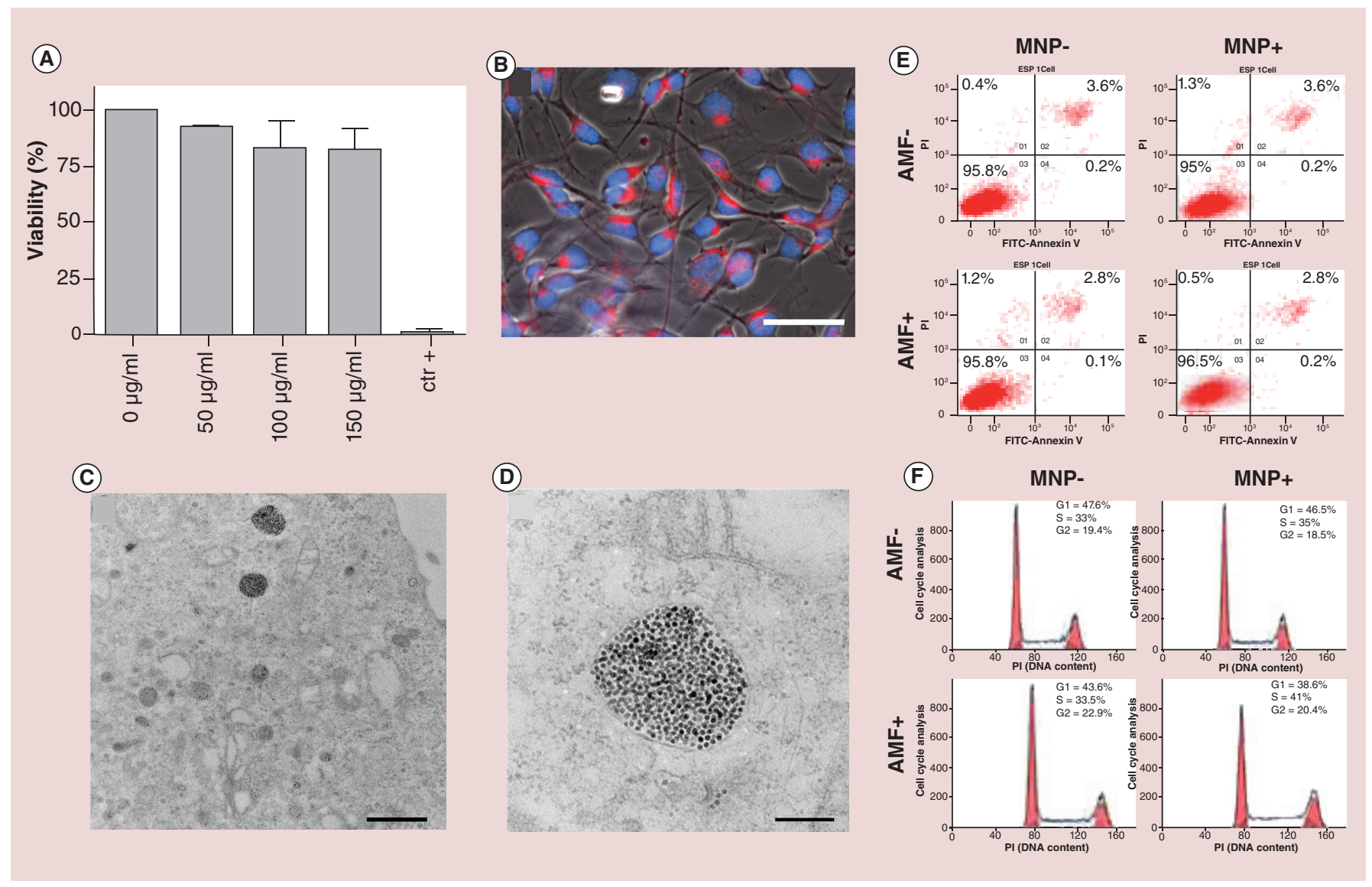

Figure 1. Viability assay and internalization of magnetic nanoparticles in B16-F10 murine melanoma cells. (A) MTT test with increasing concentrations of MNPs $(50,100$ and $150 \mu \mathrm{g} \mathrm{Fe} / \mathrm{ml})$ following $24 \mathrm{~h}$ of incubation. The measured absorbance from negative control (without MNPs) has been treated as $100 \%$ of viable cells. Cell death was assessed treating the cells with Triton X-100 as a positive control. (B) Fluorescence imaging of B16-F10 cells treated with TAMRA-labeled MNPs. The MNPs red fluorescence appears within the cytoplasm, distinct from the nucleus, stained by DAPI (blue; scale bar: $50 \mu \mathrm{m}$ ). (C) TEM images show MNPs compartmentalized into endocytic vesicles (scale bar: $1 \mu \mathrm{m}$ ). (D) High magnification of the endocytic vesicles (scale bar: $200 \mathrm{~nm}$ ).

(E) Flow cytometry plots showing B16-F10 cells distribution following annexin/propidium iodide staining. Left column: MNP-AMF- and MNP-AMF+. Right column: MNP+AMF- and MNP+AMF+. (F) Cell cycle assessment of B16-F10 melanoma cells under four different experimental conditions, as in (E). Not significant differences were shown between the different plots, indicating that the magnetic hyperthermia treatment triggered by MNPs does not affect the cell cycle.

AMF: Alternating magnetic field; MNP: Magnetic nanoparticle.

For color figures, please see online at www.futuremedicine.com/doi/full/10.2217/NNM.15.70

ature of $27^{\circ} \mathrm{C}$ ensures that the culture media temperature did not exceed $37^{\circ} \mathrm{C}$, physiological temperature, after 30-min exposure to AMF. Further controls in the absence of AMF were carried out taking into account this temperature gradient, ensuring that the observed molecular effects could solely be due to intracellular stress and not to external heat fluctuations.

Before performing the molecular assays, it was confirmed that the selected AMF conditions would not affect cell viability, using AnnexinV/propidium iodide assay, which enables to discriminate between apoptosis and necrosis, respectively. Four $\mathrm{h}$ after applying the AMF, flow cytometry analysis (Figure 1E) showed similar plots of B16-F10 cells under the four different experimental conditions: Cells incubated with MNPs and exposed to AMF (MNP+AMF+); cells incubated with MNPs and nonexposed to AMF (MNP+AMF-); cells exposed to AMF (MNP-AMF+); control cells (MNP-AMF-). Similarly, not significant differences were found in the cell cycle progression between the different experimental conditions (Figure 1F).

Once assessed that MNPs could not impair cell viability under the AMF, the extent of intracellular effects developed by MNPs using a molecular biology approach was evaluated. To date, a handful of direct methods have been reported to measure intracellular temperature using the emission intensity or lifetime of organic dyes and transition metal ions [39,40]. These methods rely on the use of probes inside the cells, which may severely affect cell physiology. Indirect measurements of intracellular heating can be achieved by studying early cellular markers, which may act as 
intracellular sensors of temperature changes. Cells respond to heat by activating a plethora of molecular pathways, which initially preserve primary cell functions and then confer thermotolerance to the changing environment [41]. One of the most characterized responses to temperature increments is the transcriptional activation of HSP genes. Among the numerous proteins belonging to the HSP superfamily, HSP70 represents the most prominent molecular chaperone in several tissues [42]. Recently, it has been elegantly shown that a transgenic $h s p$ reporter cell line, expressing the secreted bioluminescent reporter Metridia luciferase under the heat shock element (HSE), a $h s p 70$ enhancer element, may be used to monitor intracellular heat evoked by MHT or by external heat [19], confirming the appropriateness to use the transcriptional activation of this gene as a sensible marker of temperature changes for manifold applications. In line with this work, we investigated possible effects produced by MNPs under AMF exposure in B16F10 cells by monitoring the expression of $h s p 70$ gene by qRT-PCR, which allows measuring subtle fluctuations of specific transcript accumulation. Murine $h s p 70$ expression was analyzed at different points upon AMF exposure (Figure 2A), based on literature data reporting the most significant effects of heat stress on B16F10 melanoma cells around $3 \mathrm{~h}$ post-heat shock [43]. The analyses of the changes in $h s p 70$ expression levels triggered by MNPs showed a significant increase of hsp70 expression for those cells incubated with MNPs and exposed to AMF (MNP+AMF+) (Figure 2B). This effect was not observed for those cells not incubated with MNPs (MNP-AMF+) or not treated with AMF (MNP+AMF-). It must be mentioned that this increase of $h s p 70$ expression was neither observed for the control cells (MNP-AMF-) or those cells incubated at $37^{\circ} \mathrm{C}$ for $30 \mathrm{~min}$ (Supplementary Figure 4).

Unexpectedly, the highest expression (1.7-fold change) was observed immediately after the treatment, dropping off after $30 \mathrm{~min}$ to reach control values at $120 \mathrm{~min}$, indicating an early and temporally limited cell response. As B16-F10 cells have been reported to respond to external heat stress by activating $h s p 70$ expression after 3, 6 and $24 \mathrm{~h}$ [43], our findings revealing a fast $h s p 70$ upregulation might be explained by a different mechanism underlying heat generation. B16F10 cells might sense intracellular punctate heating sources (MNPs) and elicit a fast activation of $h s p 70$ to protect important cell structures and functions.

Estimation of intracellular heating mediated by magnetic hyperthermia

The heat shock response is characterized by a rapid boost in heat shock proteins upon exposure to environ- mental stresses. This evolutionarily conserved cellular mechanism is prominently regulated at transcriptional level [44]. Generally, the higher the thermal doses, the higher the $h s p 70$ expression is. In principle, this wellknown thermal kinetic may be harnessed to estimate the stress intensity induced by MNP-mediated hyperthermia through the interpolation of hsp70 expression levels measured in response to MHT to the levels measured in response to macroscopic heating. To this aim, B16-F10 cells were exposed to an external heat stress $\left(38,39,41\right.$ and $\left.43^{\circ} \mathrm{C}\right)$ over $30 \mathrm{~min}$. Despite Trypan blue assay showed no difference in survival rate induced by these heat shocks (Supplementary Figure 5), molecular analysis by qRT-PCR revealed strong $h s p 70$ overexpression at $41^{\circ} \mathrm{C}$ and $43^{\circ} \mathrm{C}(\sim 100$ - and 400 -fold increase, respectively) immediately after the treatment, reaching a maximum $30 \mathrm{~min}$ after treatment (Figure 2C). Most interestingly, heat shocking the cells at $39^{\circ} \mathrm{C}$ elicits $h s p 70$ overexpression comparable to that induced, at same time points, by AMF exposure (Figure 2B \& C \& Supplementary Figure 6). Taken together these results indicate that intracellular heating generated by MNPs during AMF exposure, while does not pose evident threats to cell survival and without surpassing $37^{\circ} \mathrm{C}$, elicits a heat shock specific molecular response. As the starting temperature of the AMF treatment was $27^{\circ} \mathrm{C}$, our data suggest that upon AMF melanoma cells respond to an intracellular hyperthermia-mediated stress similar to that induced when incubating the cells at $39^{\circ} \mathrm{C}$, in other words, by a $12^{\circ} \mathrm{C}$ increase relative to the starting condition (Supplementary Figure 6). It should be mentioned that the $h s p 70$ expression of the control cells (MNP$\mathrm{AMF}+$ ), impinged by the temperature ramp intrinsically induced by the AMF treatment, was not affected. While the intracellular stress caused by MHT has been demonstrated, further experiments should be carried out to attain an accurate value of the intracellular temperature increase, thus the $12^{\circ} \mathrm{C}$ is only a rough estimation of the MHT. It must be pointed out, that this methodology allows only the measurement of intracellular temperatures which stimulate a detectable overexpression of $h s p 70 \mathrm{mRNA}$ levels. Therefore, $h s p 70$ may fail to sense short or extremely weak heat stress stimuli. Conversely, high $h s p 70$ expression is only obtained with very high temperatures, being far of sublethal HT effects, the main aim of this study.

Although heat transfer at the nanoscale is one of the most controversial aspects of MHT, the results showed here go in line with other reports supporting the evidence that MNPs can deliver energy that gives rise to local effects. Previous work by some of us [23] and others [24] measured the local temperature at MNPs surface following AMF application in a bulk solu- 


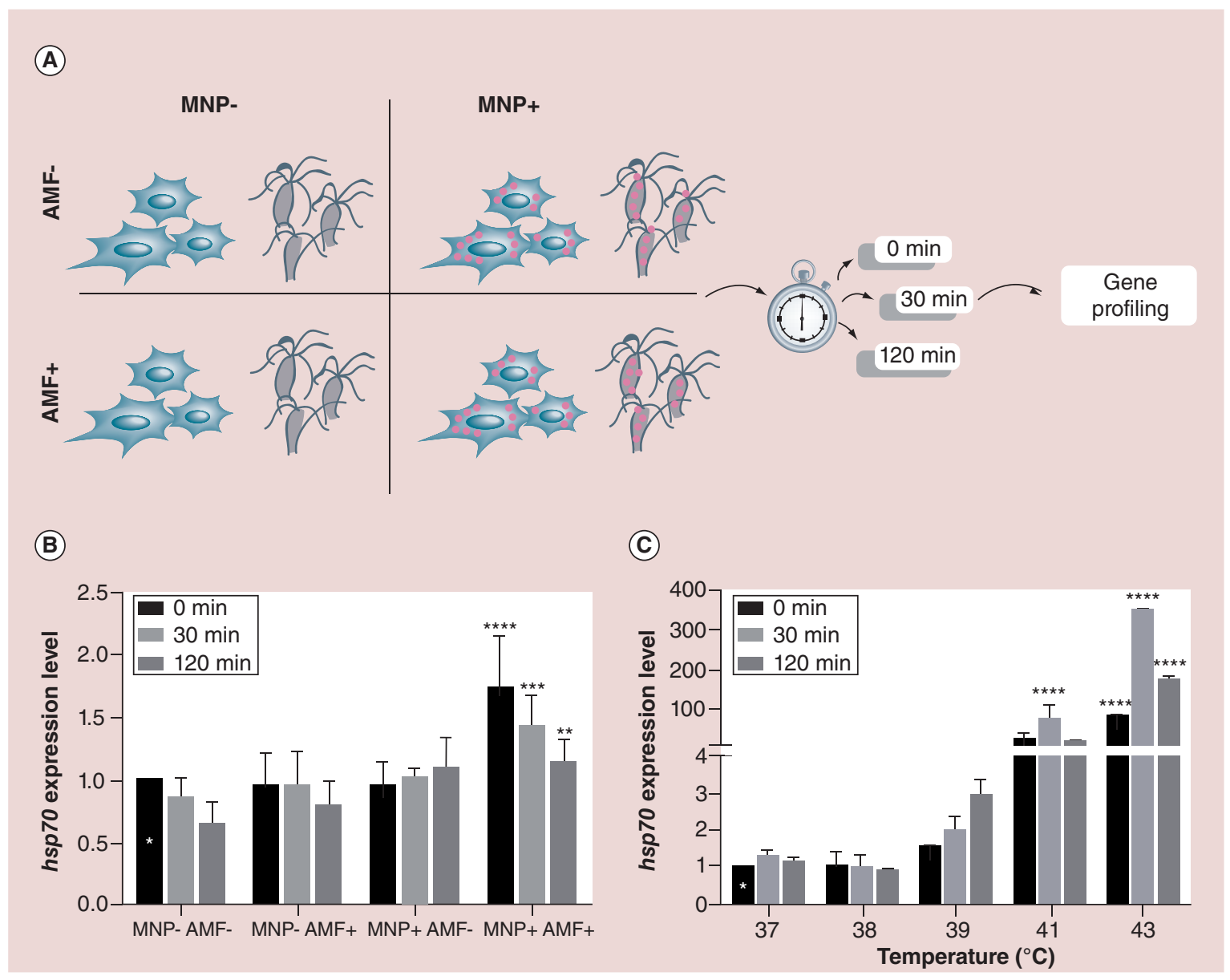

Figure 2. Magnetic nanoparticles trigger transcriptional activation of $h s p 70$ in B16-F10 melanoma cells.

(A) A scheme showing the experimental design performed with B16-F10 cells and with Hydra under four different conditions. Cells/animals were treated $24 \mathrm{~h}$ with MNPs, and following 30-min exposure to AMF or external heat, harvested for RNA extraction and real-time quantitative reverse transcription PCR (qRT-PCR) analysis at the indicated time points. MNP+AMF- and MNP-AMF+ were used as controls. (B) qRT-PCR to monitor hsp70 expression levels under the four different conditions and three time points. $h s p 70$ expression levels were compared with cells exposed to the same temperature increment intrinsically induced by AMF exposure (white star labeled column), and normalized to gadph. Black asterices show samples with normalized fold expression statistically different from their corresponding controls unexposed to AMF $(* * p<0.01 ; * * * p<0.001 ; * * * * p<0.0001$; two-way ANOVA, Tukey's multiple comparisons test). (C) hsp70 gene expression of B16-F10 cells heat shocked at different temperatures and analyzed by qRT-PCR immediately $(0 \mathrm{~min}), 30$ and $120 \mathrm{~min}$ after the treatment. Expression levels were normalized to GADPH and compared with hsp70expression relative to cells incubated at $37^{\circ} \mathrm{C}$ at time zero ( 0 min postincubation; white star). Black asterices indicate samples showing statistically different expression levels relative to their corresponding controls ( $* * * p<0.0001$; two-way ANOVA, Tukey's multiple comparisons test). AMF: Alternating magnetic field; MNP: Magnetic nanoparticle.

tion. Interestingly, following AMF under same conditions as in this work, the local temperature measured at $5 \mathrm{~nm}$ distance from MNPs surface was estimated approximately $10^{\circ} \mathrm{C}$ higher than the measured global temperature [23], suggesting MNPs acting as local delivers of thermal doses in a similar range than those observed here. Enhanced biological responses caused by MHT when compared with external heating, have also been demonstrated, although to a much lower extent than those studies made with the MNPs in solution. The concept of MNP-dependent intracellular MHT postulates that after applying an AMF, the local temperature at the NPs surface is significantly different from that of the cell surroundings; as a consequence, owing to collective effect linked to the presence of several MNPs, intracellular thermal gradient and rapid heat dissipation takes place, giving rise to biological effects $[45,46]$. Recent works demonstrated that manganese oxide perovskiteas or silica-coated manganese oxide NPs induced significant reduction of cell viability after AMF application, while the global temperature increase was lower than $0.5^{\circ} \mathrm{C}$ or not detectable at all, respectively $[47,48]$. Hence, the determination of intracellular increments of temperature mediated by 
MHT is an intriguing challenge to achieve a precise control for thermotherapies in nanomedicine.

In this work, although the overexpression of $h s p 70$ was demonstrated when applying sublethal $\mathrm{HT}$, the measurement interval was small in order to maintain the culture media below $37^{\circ} \mathrm{C}$ to assure that the stress was only due to intracellular events. Therefore, to further explore the molecular response produced by MNP-mediated MHT in vivo, we employed the aquatic invertebrate $H$. vulgaris. Normally cultured at $18^{\circ} \mathrm{C}$, Hydra allows testing the intensity of the thermal stress produced by MNPs starting from a different temperature, compared with in vitro cell culture and, in a tissue governed by different homeostasis mechanisms, thus providing an alternative model to evaluate the effect of MHT.

\section{MNP uptake \& toxicological evaluation in $H$. vulgaris}

As for cells, we first evaluated the toxicological impact and the internalization efficiency of MNPs in Hydra polyps. Living animals were soaked in culture medium supplemented with increasing doses of PEG-functionalized MNPs (from 0.25 to $2.5 \mathrm{mg}$ $\mathrm{Fe} / \mathrm{ml}$ ), and monitored at 24,48 and $72 \mathrm{~h}$ of incubation. The amount of MNPs used for the dose-response assay, much higher compared with that employed for cells, was in the range of that routinely used for Hydra when testing other nanocrystals, ensuring a reasonable probability of nanoparticle internalization by the soaking method. Toxicological evaluation was assayed through reliable tests previously developed for other chemical compounds and adapted by us to test nanoparticle toxicity, in other words, impact on morphological alterations, reproductive capability and induction of cell death [49]. For morphological tests, a score system ranging from 10 (indicative of healthy condition) to 0 (animal fully disintegrated), initially developed by Wilby, was here employed [50]. Upon microscopic inspections, treated polyps did not show traits of morphological alterations (tentacle clubbing or disintegration, body contraction or swelling), typical of metal toxicity (Supplementary Figure 7) [51]. Hydra reproduces most commonly asexually through a wellcontrolled process of budding, strictly depending on proliferation of epithelial and interstitial cells located in the body column [52]. Environmental factors, such as the presence of contaminants and food availability, can dramatically disturb this process; therefore the assessment of animal growth rate represents a reliable toxicity endpoint. Adult polyps without buds were incubated $24 \mathrm{~h}$ with MNPs $(2.5 \mathrm{mg} \mathrm{Fe} / \mathrm{ml})$ and the progeny was daily monitored over 15 days. As showed in Figure $3 \mathrm{~A}$, no significant differences were found in the growth rates of MNP-treated polyps, indicating that MNPs exposure does not affect reproductive capability. Next, we evaluated the possible occurrence of programmed cell death in treated polyps by estimating the number of pyknotic nuclei phagocyted by the gastrodermal epithelial cells, while necrotic cells were monitored in vivo by propidium iodide staining, which penetrates through damaged cell membranes labeling nucleic acids. Hydra cell suspensions obtained by maceration of MNP-treated and control polyps were stained with DAPI and monitored for chromatin fragmentation. Fluorescent microscopy observations showed no increase of pyknosis, neither significant necrosis in treated polyps compared with control animals (Figure 3B), indicating that MNPs do not induce cell death even at high concentrations, thus the $2.5 \mathrm{mg}$ $\mathrm{Fe} / \mathrm{ml}$ dose was used for all further experiments.

To track the MNP internalization in living animals, TAMRA-labeled MNPs were incubated with polyps for $24 \mathrm{~h}$. In vivo fluorescence imaging showed multiple fluorescent foci throughout the animal body indicating that MNPs enter vastly the polyps and localize massively into the ectoderm, the outer cell layer facing the environment (Figure 3D). The presence of fluorescent granular structures throughout the animal body suggests MNP accumulation into large intracellular compartments. Transmission electron microscopy revealed that MNPs localize prevalently into the lysosomes (Figure 3E \& F), usually involved in foreign material sorting out. As previously reported by our group, gold nanoparticles have also been found accumulated within lysosomes of Hydra epithelial cells [29] suggesting possible similar mechanisms of accumulation and external secretion for both nanocrystals.

To get unbiased quantification of MNPs internalization rate, we measured by ICP the intracellular Fe concentration of treated animals (24 h, MNPs $2.5 \mathrm{mg}$ $\mathrm{Fe} / \mathrm{ml})$. ICP analysis revealed the presence of $1.46 \mathrm{ng}$ $\mathrm{Fe} /$ polyp into Hydra tissues, corresponding to $0.011 \%$ of total administered iron. The iron content was normalized by subtracting the endogenous $\mathrm{Fe}$ measured in control animals as in the case of cell experimentation. All together these data indicate that MNPs internalize in Hydra polyps and do not produce detectable adverse effects at the highest tested concentration, at whole animal and cellular levels, even upon long-term exposure (72 h).

\section{Magnetic hyperthermia elicits a quantifiable heat response in $\mathrm{H}$. vulgaris}

Similar to cell experiments, MHT experiments were conducted in MNP-treated and untreated animals, either exposed or unexposed to AMF (Figure 2A). Groups of 15 polyps were incubated $24 \mathrm{~h}$ with MNPs, 

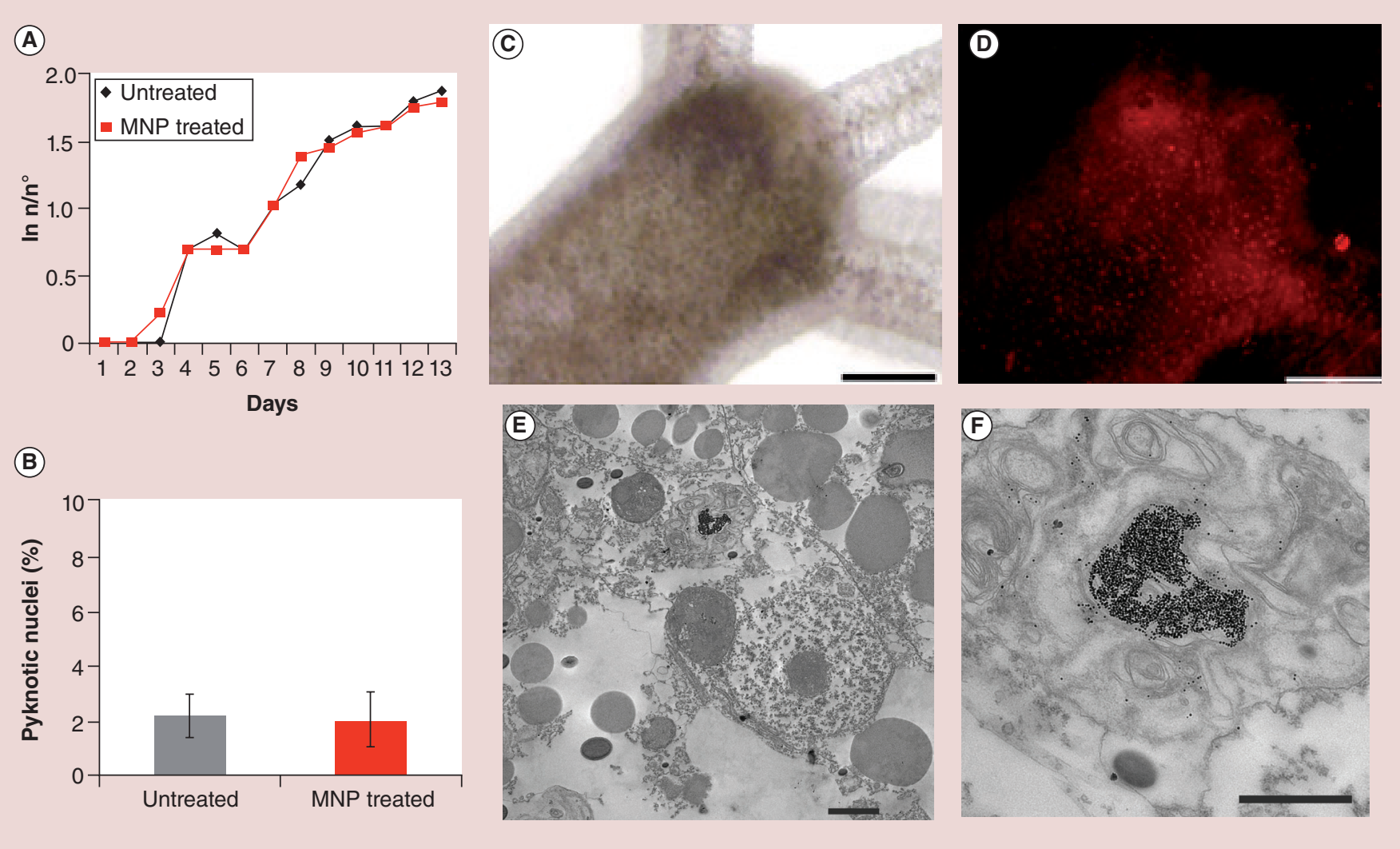

Figure 3. Biological effects, uptake and subcellular localization of magnetic nanoparticles in Hydra vulgaris. (A) Hydra population growth rate shows that MNP treatment does not affect reproduction capability in the long term. (B) Cellular assessment of apoptosis in MNP-treated animals. Following 24-h incubation with MNPs $2.5 \mathrm{mg} \mathrm{Fe} / \mathrm{ml}$, polyps were macerated in single cell suspensions and DAPI stained. No increase in the percentage of fragmented nuclei was observed in treated animals. (C) In vivo brightfield and (D) fluorescence images of Hydra polyp treated with MNPs ( $24 \mathrm{~h}, 2.5 \mathrm{mg} \mathrm{Fe} / \mathrm{ml}$ ). A punctuated red staining is clearly visible throughout the animal body indicating efficient internalization of MNPs. (E) TEM analysis shows MNPs compartmentalized into a lysosome. (F) A magnification of the lysosome from (E) shows MNPs as aggregates and monodisperse. Scale bars: $200 \mu \mathrm{m}$ in (C \& D); $2 \mu \mathrm{m}$ in (E); $1 \mu \mathrm{m}$ in (F).

MNP: Magnetic nanoparticle.

then extensively washed and exposed $30 \mathrm{~min}$ to AMF $(f=835 \mathrm{kHz} ; \mathrm{H}=20.05 \mathrm{kA} / \mathrm{m})$. During the AMF exposure, the Hydra medium temperature was constantly monitored through an optical fiber thermometer, which reported a negligible temperature increment (approximately of $2^{\circ} \mathrm{C}$ ) in the medium bathing the animals. Microscopic observations performed on intact living animals immediately after AMF did not reveal tissue damages or cell detachments from body surface, suggesting that, similar to the cell experiments, MNPs could not induce cell ablation. DAPI staining on macerates (i.e., fixed cell suspensions obtained from treated animals) confirmed the absence of increased cell death upon magnetic treatments (Supplementary Figure 8). In order to assess molecular responses to AMF, we profiled the expression of Hydra hsp70 homologous gene (byhsp70), already cloned and functionally characterized as early marker of heat shock in Hydra species [53]. Following AMF exposure, polyps were allowed to recover 30 and 120 min before RNA extraction and qRT-PCR analysis. Results from Figure 4A showed a twofold overexpression of hyhsp70 transcripts 120 min posttreatment in animals loaded with MNPs and exposed to AMF (MNP+AMF+), but not in any other condition (MNP+AMF-; MNP-AMF+; MNP-AMF-), showing a heat-specific response triggered by MNPs and induced by AMF. These data confirm that, under an AMF, MNPs produce mild intracellular heating, which does not affect polyp viability and tissue integrity, while triggering a heat shock specific response. To compare the observed MHT effects to the innate response of Hydra to high temperatures, we heat shocked the polyps for $30 \mathrm{~min}$ at different increasing temperatures (by supplying external heating through bath incubation) and explored the molecular response after 30 and $120 \mathrm{~min}$ of recovery at $18^{\circ} \mathrm{C}$. As shown in Figure 4B, hyssp70 gene expression was slightly activated at $26^{\circ} \mathrm{C}(\sim 1.5$-fold increase) reaching the highest expression at $30^{\circ} \mathrm{C}(\sim$ twofold increase, $120 \mathrm{~min}$ 
(A)

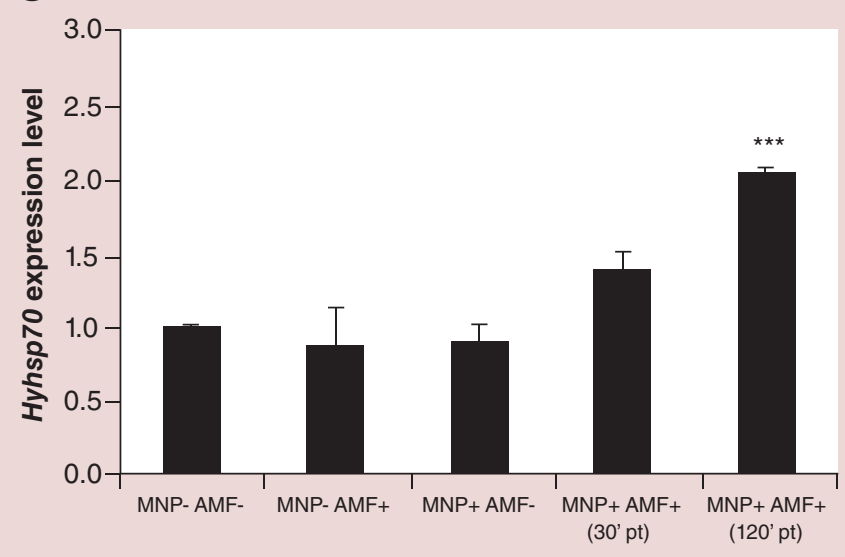

(B)

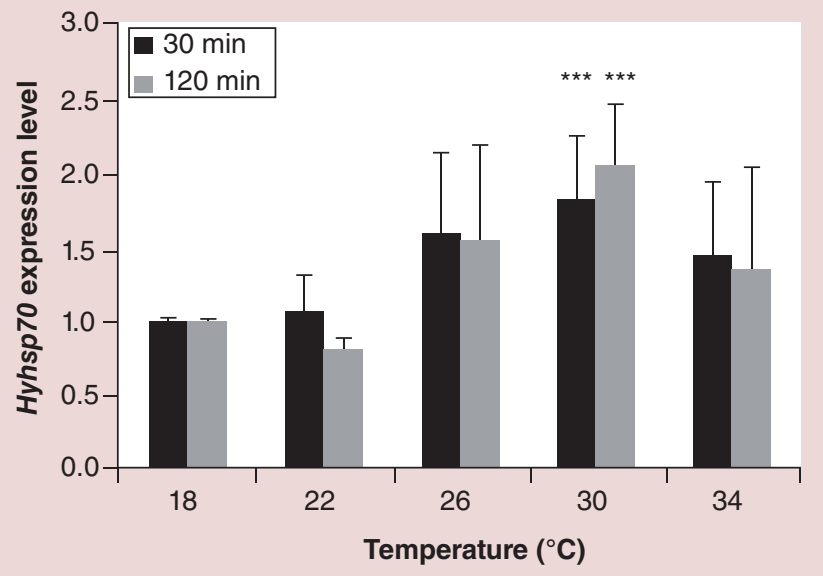

(F)

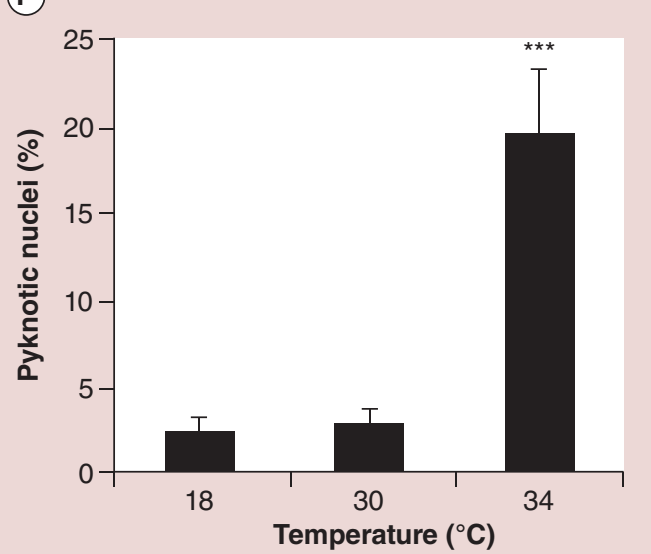

Figure 4. Magnetic nanoparticles trigger transcriptional activation of hyhsp70 in Hydra. (A) AMF exposure of MNP-treated polyps induces a twofold change of hyhsp70 expression, while MNPs and AMF exposure alone did not modulate hyhsp70 expression. Asterices denote statistically significant expression change relative to untreated animals (one-way ANOVA followed by Tukey's multiple comparison post-test, $\mathrm{p}<0.001$ ). (B) Molecular response to macroscopic heat shock in Hydra. Real-time quantitative reverse transcription PCR analysis revealed that hsp70 is significantly upregulated at $30^{\circ} \mathrm{C}$. Asterices indicate statistical significance $(p<0.001$; two-way ANOVA with Bonferroni's multiple comparison post-test). (C, D \& E) Heat shock effects on Hydra morphology. (C) Exposure to $30^{\circ} \mathrm{C}$ does not affect $H y d r a$ phenotype, while (D) incubation at $34^{\circ} \mathrm{C}$ produces slight body contraction and animal paralysis.

(E) Short incubation at $37^{\circ} \mathrm{C}$ provokes devastating effects and tissues appear completely disintegrated. (F) Assessment of apoptosis. Incubation at $34^{\circ} \mathrm{C}$ for $24 \mathrm{~h}$ induces a significant increase of apoptotic nuclei (one-way ANOVA followed by Tukey's multiplecomparison post-test, $\mathrm{p}<0.001$ ). Scale bars: $500 \mu \mathrm{m}$ in (C \& D); $200 \mu \mathrm{m}$ in (E). AMF: Alternating magnetic field; MNP: Magnetic nanoparticle.

post-stress), while higher temperatures did not affect transcript levels. Besides molecular analysis, for each temperature the animal morphology and cell viability induced were analyzed. Microscope inspection revealed no evident morphological alterations up to $30^{\circ} \mathrm{C}$ (Figure $4 \mathrm{C}$ ), while above this value progressive tissue damages appeared up to irreversible tissue disintegration at $37^{\circ} \mathrm{C}$ (Figure $4 \mathrm{E} \&$ Supplementary Figure 9) in line with existing literature [53].

At $34^{\circ} \mathrm{C}$, animals showed behavioral alterations (slight body contraction, paralysis and absence of response to mechanical stimuli) but not evident cell damages (Figure 4D); if transferred to physiological growth conditions $\left(18^{\circ} \mathrm{C}\right)$, these animals could recover their normal explorative behavior, indicating $34^{\circ} \mathrm{C}$ as a critical temperature, above which extensive tissue damages and animal death occur, while below thermotolerance mechanism prevails. Thus we tested the induction of apoptosis and found a significant higher percentage of phagocyted pyknotic nuclei following heat shock at $34^{\circ} \mathrm{C}$, but not at $30^{\circ} \mathrm{C}$ (Figure 4F), confirming that even in absence of clear morphological alterations this temperature impairs cell viability in Hydra. By comparing data obtained from heat stress and MHT responses, it appears that MHT provides sublethal thermal doses not sufficient to affect animal health, but measurable by a twofold hyhsp70 overexpression. This response is similar to 
that observed when Hydra is exposed to a temperature increase up to $30^{\circ} \mathrm{C}$, thus to an increment of $12^{\circ} \mathrm{C}$.

Impressively, this temperature increase is comparable to that observed in cells in response to the same solicitation (Figure 5). We showed that, although presenting different complexity and thermal homeostasis mechanisms, the two biological models analyzed in this study elicit similar molecular response when challenged with MNPs. Both B16-F10 cells and Hydra, treated with MNPs and exposed to AMF react to intracellular thermal stress by enhancing defence gene transcription (such as $h s p 70$ ) to tolerate the heat. We are aware that the AMF employed in this work has an intensity well above those allowed for clinical application $(f=110 \mathrm{kHz} ; \mathrm{H}=20 \mathrm{kA} / \mathrm{m})[54]$ and indeed lower fields and frequencies may be tested to optimize the heat delivered inside a cell.

Nowadays, the quantification of the intracellular thermal effect caused by MNPs following AMF exposure is a challenge, together with the determination of all possible effects elicited in the cells by radiofrequencies. Besides heat generation, other mechanisms are in fact being suggested to explain the effect of MNPs following AMF, such as mechanical forces driving lysosome destruction and release of toxic compounds leading to cell death $[55,56]$. Physical parameters from one side and biological responses from the others, all need to be taken into account to explain how cells respond to internalized metal nanoparticles following energy absorption and transformation into heat or other energy forms. Herein, we showed that under an AMF and without surpassing $37^{\circ} \mathrm{C}$, the MNPs synthetized in this study evoke in cells a response typical to that elicited by macroscopic heat, in other words, cells overexpress chaperones to ensure proper protein folding and avoid structural changes due to enhanced heat. Thus, in absence of direct means to measure intracellular temperature, we quantified molecular motors generally involved in heat stress and found their enhancement in cell/animals treated with MNPs and AMF, suggesting MNPs behaving as nano-hot spots inside the cells. What strongly support our hypothesis that MNPs act as nanoheater are the findings that the $h s p 70$ expression levels profile similarly in MHT treated cells/animals and heat shocked cells/animals, two biological models of different complexity (a murine cancer cell line and a primitive eukaryotic animal at the base of metazoan evolution) respond in a same way to the same solicitation: the hsp70 expression levels in both systems double as effect of MNPs + AMF treatment or of a macroscopic heating, raising the external temperature of $12^{\circ} \mathrm{C}$. The delta between the starting and the final temperatures seems the crucial factor, rather than the absolute temperature values, providing a valuable feedback to understand in vivo the thermal properties of a given nanomaterial. Although we cannot exclude other possibilities as HSPs participate in several other cell pathways beside heat stress (i.e., they protect cells against oxidative injuries) [57], it is unlikely that a response could be due to a stress different than heat,

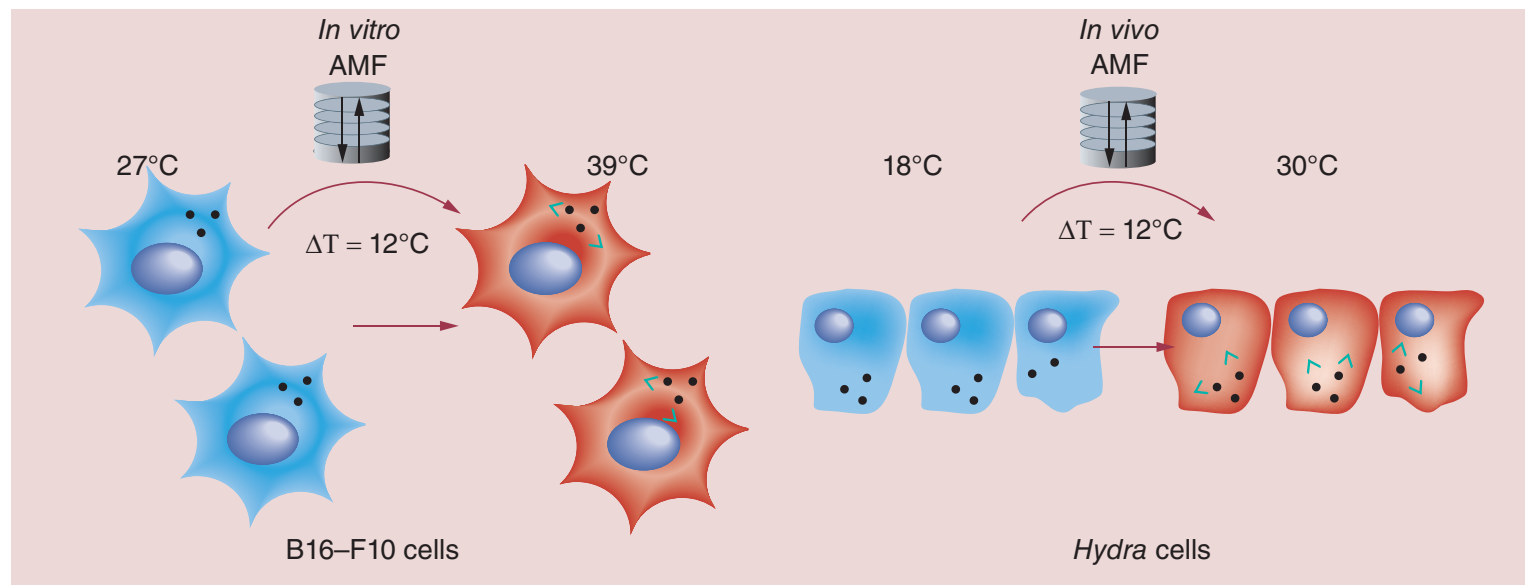

Figure 5. Paralleling molecular effects generated in cells and Hydra by magnetic hyperthermia. A model is suggested showing similarities between responses evoked in the two diverse systems by magnetic nanoparticles (MNPs). Following AMF exposure, B16-F10 cells show no evident effects of toxicity at macroscopic/cellular level but at molecular level $h s p 70$ overexpression is observed, mirroring that induced by heat shocking the cells at $39^{\circ} \mathrm{C}$, thus by shifting of $12^{\circ} \mathrm{C}$ the initial experimental temperature $\left(27^{\circ} \mathrm{C}\right)$. In Hydra, MNP treatment alone does not induce toxicity effects. Exposure to AMF neither affects viability, but induces a doubling of hyhsp70 transcripts. This enhancement mirrors that induced by exposing polyps at $30^{\circ} \mathrm{C}$ (in a thermal bath), namely by a shift of $12^{\circ} \mathrm{C}$ above the initial temperature $\left(18^{\circ} \mathrm{C}\right)$. Altogether the data show same cell and animal response to MNP-mediated hyperthermia, suggesting their combined use to assess the thermal dose delivered by MNPs in vivo. Green arrows represent local heat production.

AMF: Alternating magnetic field. 
highlighting the importance to include comparative analysis in different models for preclinical trials.

Moreover, our biological systems represent a valuable tool to assess nanoparticle properties in situ. Indeed, despite more or less accurate estimations of the thermal properties of MNPs performed in physiological media, their behavior once delivered and accumulated inside the cell (cytoplasm, endosome and lysosome) together with their state (aggregated and monodispersed) may profoundly impact on thermal properties [58]. Our study proposes an integrated cell-oriented approach to cover this unsolved issue, with the final goal to control intracellular temperature increase for biomedical applications. Understanding the molecular mechanisms underlying cellular responses to sublethal hyperthermia such as hsp70 overexpression (and its kinetics) will contribute to the enhancement of cancer therapies, in other words, by gaining knowledge on the transient thermotolerance [18]. Moreover, by finely tuning MNP properties and magnetic fields, a strict control of the amount of heat generated by intracellular nanosized sources may trigger localized apoptotic pathways, avoiding undesired effects in surrounding tissues as it occurs for gold nanoparticles and photothermal therapy treatments [59]. Hyperthermia, in fact, can influence cell processes and fate as function of the thermal dose applied. In this study, we expanded this widely accepted concept and showed that also mild hyperthermia may determinate the activation of specific molecular pathways in vitro and in vivo.

\section{Conclusion}

There is a growing interest for the engineering of MNPs with superior magnetic properties specifically tuned for hyperthermia-based therapies. Although physico-chemical characterization provides initial clues on material properties and heating performance, understanding how and to what extent cells respond to the intracellular nanoheaters is of primary importance for biomedical applications. Here, we propose to measure the thermal stress induced by MNPs and AMF by molecular investigations. Enhanced biological responses caused by MHT when compared with external heating have been demonstrated without surpassing $37^{\circ} \mathrm{C}$ in the case of cells. Taken into account that cell types and tissues have different heat sensitivity, our strategy is a viable route to screen and predict MNP properties required to establish appropriate nanomedicine-based thermotherapies.

Not least, it remains of outstanding interest unraveling the molecular mechanisms involved in heat stress perception and signaling generated by a nonconventional thermal stress, where the heat comes from inside the cells and not from the environment.

\section{Future perspective}

Sublethal HT is gaining importance in cancer therapy. When applied in combination with other treatments such as chemotherapy, a synergistic interaction between heat and these treatments has been demonstrated, avoiding unnecessary burning in healthy tissues. However, accomplishing the required temperatures resulting from preclinical data under clinical conditions is not an easy task. Understanding the mechanism of heat transfer from MNP-mediated HT to cells and tissues will contribute to the enhancement of this therapy. Therefore, studies performed to study what cells really sense when an AMF is being applied appear an urgent need. In this study, it has been demonstrated that cells can respond to MNP-mediated HT without global temperature increase, and in a different fashion than when applying macroscopic heating. More interestingly, these responses are comparable to those evoked in vivo in a complex organism, $H$. vulgaris. Future investigations using other stress genes may impact on therapeutic application of magnetic HT.

\section{Acknowledgements}

The authors thank G Marino, S Rivera and I Echaniz for technical support; Stazione Zoologica Anton Dohrn and Laboratorio de Microscopía Avanzada for access to TEM, I Ochoa for access to qRT-PCR and CIBA for access to FACS facilities.

\section{Financial \& competing interests disclosure}

The authors thank NanoSciEraNet project NANOTRUCK for financial support. JM de la Fuente thanks ERC-Starting Grant 239931-NANOPUZZLE project and Fondo Social Europeo (FSE; Gobierno de Aragón) for financial support. The authors have no other relevant affiliations or financial involvement with any organization or entity with a financial interest in or financial conflict with the subject matter or materials discussed in the manuscript apart from those disclosed.

No writing assistance was utilized in the production of this manuscript.

\section{Ethical conduct of research}

The authors state that they have obtained appropriate institutional review board approval or have followed the principles outlined in the Declaration of Helsinki for all human or animal experimental investigations. In addition, for investigations involving human subjects, informed consent has been obtained from the participants involved.

\section{Open access}

This work is licensed under the Creative Commons Attribution-NonCommercial 3.0 Unported License. To view a copy of this license, visit http://creativecommons.org/licenses/bync-nd/3.0/ 


\section{Executive summary}

\section{Objective}

- To study intracellular thermal response after having applied an alternating magnetic field (sublethal hyperthermia) or macroscopic heat into two model systems.

\section{Experimental setup}

- Iron oxide nanoparticles of $16 \mathrm{~nm}$ were synthetized and loaded into murine melanoma cells and Hydra vulgaris, recently emerged as an excellent model for high-throughput screening of nanoparticles bioactivity and toxicity.

- Both model systems were subjected to an alternating magnetic field system or or to external heating in an incubator. In both cases, the same global temperature was reached, so that the measured thermal stress was solely due to the magnetic hyperthermia and not to external heat fluctuations.

- The expression of hsp70 gene was assessed by real-time quantitative reverse transcription PCR.

\section{Results}

- Magnetic hyperthermia can induce thermal stress even without surpassing $37^{\circ} \mathrm{C}$ in the case of cells or $18^{\circ} \mathrm{C}$ in the case of Hydras. The analyses of the changes in hsp70 expression levels triggered by MNPs showed a significant increase of $h s p 70$ expression for those cells incubated with MNPs and exposed to an alternating magnetic field in both model systems.

- Through the interpolation of $h s p 70$ expression levels measured in response to magnetic hyperthermia and macroscopic heating, the two biological models elicit similar molecular response, sensing an intracellular increment of $\sim 12^{\circ} \mathrm{C}$ upon magnetic hyperthermia application.

\section{Conclusion}

- Magnetic hyperthermia stressed the cells in a different way than macroscopic heat.

- Both model systems responded similar to the same solicitation, suggesting a general mechanism underlying the response of eukaryotic cells to the delivery of sublethal thermal doses.

\section{References}

Papers of special note have been highlighted as:

- of interest; $\bullet \bullet$ of considerable interest

1 Hao R, Xing R, Xu Z, Hou Y, Gao S, Sun S. Synthesis, functionalization, and biomedical applications of multifunctional magnetic nanoparticles. Adv. Mater. 22(25), 2729-2742 (2010).

2 Reddy LH, Arias JL, Nicolas J, Couvreur P. magnetic nanoparticles: design and characterization, toxicity and biocompatibility, pharmaceutical and biomedical applications. Chem. Rev. 112, 5818-5878 (2012).

3 Kumar CSSR, Mohammad F. Magnetic nanomaterials for hyperthermia-based therapy and controlled drug delivery. Adv. Drug Deliv. Rev. 63(9), 789-808 (2011).

4 Mornet S, Vasseur S, Grasset F, Duguet E. Magnetic nanoparticle design for medical diagnosis and therapy. J. Mater. Chem. 14(14), 2161-2175 (2004).

5 Berry CC. Progress in functionalization of magnetic nanoparticles for applications in biomedicine. J. Phys. D Appl. Phys. 42(22), 224003 (2009).

6 Berry CC, Curtis ASG. Functionalisation of magnetic nanoparticles for applications in biomedicine. J. Phys. D Appl. Phys. 36(13), R198-R206 (2003).

7 Goya GF, Lima E, Arelaro AD et al. Magnetic hyperthermia with $\mathrm{Fe}_{3} \mathrm{O}_{4}$ nanoparticles: the influence of particle size on energy absorption. IEEE Trans. Magn. Magn. 44(11), 4444-4447 (2008).

8 Gilchrist RK, Medal R, Shorey WD, Hanselman RC, Parrott JC, Taylor CB. Selective inductive heating of lymph nodes. Ann. Surg. 146(4), 596-606 (1957).
9 Basel MT, Balivada S, Wang HW et al. Cell-delivered magnetic nanoparticles caused hyperthermia-mediated increased survival in a murine pancreatic cancer model. Int. J. Nanomedicine 7, 297-306 (2012).

10 Johannsen M, Gneueckow U, Thiesen B et al. Thermotherapy of prostate cancer using magnetic nanoparticles: feasibility, imaging, and three-dimensional temperature distribution. Eur. Urol. 52(6), 1653-1662 (2007).

11 Toraya-Brown S, Sheen MR, Zhang P et al. Local hyperthermia treatment of tumors induces $\mathrm{CD} 8^{+} \mathrm{T}$ cellmediated resistance against distal and secondary tumors. Nanomedicine 10(6), 1273-1285 (2014).

12 Maier-Hauff K, Ulrich F, Nestler D et al. Efficacy and safety of intratumoral thermotherapy using magnetic iron-oxide nanoparticles combined with external beam radiotherapy on patients with recurrent glioblastoma multiforme. J. Neurooncol. 103(2), 317-324 (2011).

13 Dewey WC. Arrhenius relationships from the molecule and cell to the clinic. Int. J. Hyperthermia 25(1), 3-20 (2009).

14 Kobayashi T. Cancer hyperthermia using magnetic nanoparticles. Biotechnol. J. 6(11), 1342-1347 (2011).

15 Wust P, Hildebrandt B, Sreenivasa G et al. Hyperthermia in combined treatment of cancer. Lancet Oncol. 3(8), 487-497 (2002).

16 Ryu KS, Kim JH, Ko HS et al. Effects of intraperitoneal hyperthermic chemotherapy in ovarian cancer. Gynecol. Oncol. 94(2), 325-332 (2004).

17 Franckena M, Stalpers LJA, Koper PCM et al. Long-term improvement in treatment outcome after radiotherapy and hyperthermia in locoregionally advanced cervix cancer: an update of the Dutch Deep Hyperthermia Trial. Int. J. Radiat. Oncol. Biol. Phys. 70(4), 1176-1182 (2008). 
18 Roti Roti J. Cellular responses to hyperthermia (40-46 degrees C): cell killing and molecular events. Int. J. Hyperthermia 24(1), 3-15 (2008).

19 Mukherjee A, Castanares M, Hedayati M et al. Monitoring nanoparticle-mediated cellular hyperthermia with a high-sensitivity biosensor. Nanomedicine (Lond.) 9(18), 2729-2743 (2014).

- Presents a very smart temperature-sensitive secreted luciferase-based reporter gene system to study thermal stress response at the cellular level, in response to macroscopic and nanoparticle hypethermia.

20 Jolly C, Morimoto RI. Role of the heat shock response and molecular chaperones in oncogenesis and cell death. J. Natl Cancer. Inst. 92(19), 1564-1572 (2000).

21 Ito A, Honda H, Kobayashi T. Cancer immunotherapy based on intracellular hyperthermia using magnetite nanoparticles: a novel concept of "heat-controlled necrosis" with heat shock protein expression. Cancer Immunol. Immunother. 55, 320-328 (2006).

- Shows that magnetic hyperthermia induces $h s p$ overexpression to protect cells from heat-induced apoptosis.

22 Hegyi G, Szigeti GP, Szász A. Hyperthermia versus oncothermia: cellular effects in complementary cancer therapy. Evid. Based Complement. Alternat. Med. 2013, 672873 (2013).

23 Dias JT, Moros M, Del Pino P, Rivera S, Grazú V, de la Fuente JM. DNA as a molecular local thermal probe for the analysis of magnetic hyperthermia. Angew. Chem. Int. Ed. Engl. 52(44), 11526-11529 (2013).

- Using DNA molecules attached to the surface of magnetic nanoparticles, the local temperature at their surface following alternating magnetic field application is measured.

24 Riedinger A, Guardia P, Curcio A et al. Subnanometer local temperature probing and remotely controlled drug release based on azo-functionalized iron oxide nanoparticles. Nano Lett. 13(6), 2399-2406 (2013).

25 Ambrosone A, Malvindi MA, Roopin M, et al. Impact of amorphous $\mathrm{SiO}_{2}$ nanoparticles on a living organism: morphological, behavioral, and molecular biology implications. Front. Bioeng. Biotechnol. 2, 37 (2014).

26 Ambrosone A, del Pino P, Marchesano V, Parak WJ, de la Fuente JM, Tortiglione C. Gold nanoprisms for photothermal cell ablation in vivo. Nanomedicine (Lond.) 9(13), 1913-1922 (2014).

- Demonstrates that Hydra may serve as a suitable model to investigate cell and molecular effects triggered by nanoparticle-mediated hyperthermia.

27 Ambrosone A, Mattera L, Marchesano V et al. Mechanisms underlying toxicity induced by $\mathrm{CdTe}$ quantum dots determined in an invertebrate model organism. Biomaterials 33(7), 1991-2000 (2012).

28 Conde J, Ambrosone A, Sanz V et al. Design of multifunctional gold nanoparticles for in vitro and in vivo gene silencing. ACS Nano 6(9), 8316-8324 (2012).
29 Marchesano V, Hernandez Y, Salvenmoser W et al. Imaging inward and outward trafficking of gold nanoparticles in whole animals. ACS Nano 7(3), 2431-2442 (2013).

30 Sun S, Zeng $\mathrm{H}$, Robinson $\mathrm{DB}$ et al. Monodisperse $\mathrm{MFe}_{2} \mathrm{O}_{4}$ $(\mathrm{M}=\mathrm{Fe}, \mathrm{Co}, \mathrm{Mn})$ nanoparticles. J. Am. Chem. Soc. 126(1), 273-279 (2004).

31 Moros M, Pelaz B, López-Larrubia P, García-Martin ML, Grazú V, de la Fuente JM. Engineering biofunctional magnetic nanoparticles for biotechnological applications. Nanoscale 2(9), 1746-1755 (2010).

32 Moros M, Hernáez B, Garet E et al. Monosaccharides versus PEG functionalized nps: influence in the cellular uptake. ACS Nano 6(2), 1565-1577 (2012).

33 Loomis W, Lenhoff HM. Growth and sexual differentiation of Hydra in mass culture. J. Exp. Zool. 132, 555-574 (1956).

34 Lasi M, David CN, Bottger A. Apoptosis in pre-Bilaterians: Hydra as a model. Apoptosis 15(3), 269-278 (2010).

35 Primer3. http://frodo.wi.mit.edu/primer3

36 Livak KJ, Schmittgen TD. Analysis of relative gene expression data using real-time quantitative PCR and the 2(T)(-Delta Delta C) method. Methods 25(4), 402-408 (2001).

37 Kariya A, Tabuchi Y, Yunoki T, Kondo T. Identification of common gene networks responsive to mild hyperthermia in human cancer cells. Int. J. Mol. Med. 32(1), 195-202 (2013).

38 Grazu V, Silber AM, Moros M et al. Application of magnetically induced hyperthermia in the model protozoan Crithidia fasciculata as a potential therapy against parasitic infections. Int. J. Nanomedicine 7, 5351-5360 (2012).

39 Gota C, Okabe K, Funatsu T, Harada Y, Uchiyama S. Hydrophilic fluorescent nanogel thermometer for intracellular thermometry. J. Am. Chem. Soc. 131(8), 2766-2767 (2009).

40 Suzuki M, Tseeb V, Oyama K, Ishiwata SI. Microscopic detection of thermogenesis in a single hela cell associated with the increase in $\mathrm{Ca}^{2+}$ concentration induced by ionomycin. Biophys. J. 92(6), L46-L48 (2007).

41 Morimoto RI. Regulation of the heat shock transcriptional response: cross talk between a family of heat shock factors, molecular chaperones, and negative regulators. Genes Dev. 12(24), 3788-3796 (1998).

42 Mayer MP, Bukau B. Hsp70 chaperones: cellular functions and molecular mechanism. Cell. Mol. Life Sci. 62(6), 670-684 (2005).

43 Garcia MP, Cavalheiro JRT, Fernandes MH. Acute and longterm effects of hyperthermia in B16-F10 melanoma cells. PLoS ONE 7(4), e35489 (2012).

- Shows that macroscopic hyperthermia treatment induces hsp70 gene overexpression in the same cell line used in this paper.

44 Pirkkala L, Nykanen P, Sistonen L. Roles of the heat shock transcription factors in regulation of the heat shock response and beyond. FASEB J. 15(7), 1118-1131 (2001).

45 Huang H, Delikanli S, Zeng H, Ferkey DM, Pralle A. Remote control of ion channels and neurons 
through magnetic-field heating of nanoparticles. Nat. Nanotechnol. 5(8), 602-606 (2010).

Ogden JA, Tate JA, Strawbridge RR, Ivkov R, Hoopes PJ. Comparison of iron oxide nanoparticle and waterbath hyperthermia cytotoxicity. Proc. Soc. Photo Opt. Instrum. Eng. 7181, 71810K (2009).

47 Creixell M, Bohorquez AC, Torres-Lugo M, Rinaldi C. EGFR-targeted magnetic nanoparticle heaters kill cancer cells without a perceptible temperature rise. ACS Nano 5(9), 7124-7129 (2011).

- Demonstrates that magnetic nanoparticles can kill cancer cells after having applied an alternating magnetic field without a global temperature increase.

48 Villanueva A, de la Presa P, Alonso JM et al. Hyperthermia HeLa cell treatment with silica-coated manganese oxide nanoparticles. J. Phys. Chem. C 114(5), 1976-1981 (2010).

49 Ambrosone A, Tortiglione C. Methodological approaches for nanotoxicology using cnidarian models. Toxicol. Mech. Methods 23(3), 207-216 (2013).

50 Wilby OK, Tesh JM. The Hydra assay as a nearly screen for teratogenic potential. Toxicol. In Vitro 4, 582-583 (1990).

51 Pollino CA, Holdway DA. Potential of two Hydra species as standard toxicity test animals. Ecotoxicol. Environ. Saf. 43(3), 309-316 (1999).

52 Bosch T, David C. Growth regulation in Hydra: relationship between epithelial cell cycle length and growth rate. Dev. Biol. 104(1), 161-171 (1984).
53 Bosch T, Krylow SM, Bode H, Steele R. Thermotolerance and synthesis of heat shock proteins: these responses are present in Hydra attenuata but absent in Hydra oligactis. Proc. Natl Acad. Sci. USA 85(21), 7927-7931 (1988).

54 Maier-Hauff K, Rothe R, Scholz R et al. Intracranial thermotherapy using magnetic nanoparticles combined with external beam radiotherapy: results of a feasibility study on patients with glioblastoma multiforme. J. Neurooncol. 81(1), 53-60 (2007).

55 Marcos-Campos I, Asin L, Torres TE et al. Cell death induced by the application of alternating magnetic fields to nanoparticleloaded dendritic cells. Nanotechnology 22(20), 205101 (2011).

56 Asin L, Ibarra MR, Tres A, Goya GF. Controlled cell death by magnetic hyperthermia: effects of exposure time, field amplitude, and nanoparticle concentration. Pharm. Res. 29(5), 1319-1327 (2012).

57 Polla BS, Kantengwa S, Francois D et al. Mitochondria are selective targets for the protective effects of heat shock against oxidative injury. Proc. Natl Acad. Sci. USA 93(13), 6458-6463 (1996).

58 Di Corato R, Espinosa A, Lartigue L et al. Magnetic hyperthermia efficiency in the cellular environment for different nanoparticle designs. Biomaterials 35(24), 6400-6411 (2014).

59 Perez-Hernandez M, Del Pino P, Mitchell SG et al. Dissecting the molecular mechanism of apoptosis during photothermal therapy using gold nanoprisms. ACS Nano 9(1), 52-61 (2015). 